\title{
Review of different propagation media for potato mini tuber production under screen house
}

\author{
Egata Shunka Tolessa \\ Ethiopian Institute of Agricultural Research, Holetta Agricultural Research Center, Crop Research Process, Potato \\ Research Program, Addis Ababa, Ethiopia. \\ Email: egata.shunka@yahoo.com/eshunka2007@gmail.com
}

Copyright (C) 2021 Tolessa. This article remains permanently open access under the terms of the Creative Commons Attribution License 4.0, which permits unrestricted use, distribution, and reproduction in any medium, provided the original work is properly cited.

Received 15th January, 2021; Accepted 16th March, 2021

\begin{abstract}
Scarcities of healthy and quality potato tuber seeds are the problem of the production of potatoes in the world. Especially, in developing countries it is a serious problem that cause decline in the production and productivity of the potatoes and hampers the profits of producers. To alleviate this problem, many countries produce the mini tubers in screen house from diseases-free planting materials in pots or seed bade made of pathogen-free media. Most reviewed papers indicated that a media used to grow potato in screen houses are made of a combination of different substrates for the suitability of the crop gown on it as it provides sufficient nutrients, aeration, support, and water. Developed countries use rock wool, vermiculite, peat, and other expensive media made by factories while the underdeveloped use cheap materials that are easily available in their surroundings like forest soil, sand, compost, and FYM (farm yard manure). There is also limited research concerning these materials in developing countries, especially, about the ratio of mixing and types to be mixed. The expensive materials used for pot media making are not found in Ethiopia though there are surplus raw materials. Therefore, this review was conducted to assess the information available about the different screen house growing media used worldwide and conceptualize for future utilization. It is concluded that researchers should work on the availability of healthy and quality tuber seed by increasing the numbers produced in screen house through agronomic and other techniques of production solving problems related to potting media.
\end{abstract}

Keywords: Compost, FYM, peat, seed tubers, vermicompost, vermiculite.

\section{INTRODUCTION}

Potato is one of the highly productive crops of the high lands of the world. Its production depends on the inputs applied, and the soil media where potatoes growing take place. Especially in screen house where potato minitubers are produced in pots, the amount of the soil media filled to pots and the content of the soil media filled to the pots are found to be adversely affecting mini-tuber production (Sharma and Pandey, 2013) as it is supposed to provide sufficient nutrients, aeration, support, and water. Scarcities of healthy and quality potato tuber seeds are the problem of the production of potatoes in the world. It is not available in the amount required for the producers in almost all countries of the world, especially, in developing countries, it is a serious problem that cause decline in the production and productivities of the potatoes and hampers the profits of producers. To alleviate this problem, many countries produce the mini tubers in screen house from diseases-free planting materials in pots or seed bade made of pathogen-free media. Field soil was reported as not satisfying potato production medium in the pot under screen house (Zimba et al., 2014). This is because soil cannot supply sufficient aeration, drainage, and water holding capacity (Albajes et al., 2002). The addition of sand and FYM (farm yard manure) can improve the aeration, drainage, and the water holding capacity. Other media like sawdust, vermiculit, perlite, sphagnum, peat, pumice, styroform, compost, and sand are used for growing plantlets in screen house (Balali et al., 2008). 
Expensive medium like rock wool was used as the best media in Northen Europe (Zimba et al., 2014). According to Zimba et al. (2014), vermicullite and rock wool are very expensive media while developing countries requiring locally available cheap material (Mobini et al., 2009). Forest soil, sand soil, and FYM are cheap and locally available alternative media that can substitute these expensive media though the best combination of the three needs to be identified that encourage mini-tuber production improving soil drainage, aeration, and water holding capacity aspects.

Another production constraint is the lack of quality basic seed (Aheisibwe et al., 2015). Acceptable quality seeds are the critical concern of farmers and researchers (Roy, 2014 ) as it ensures a harvest increase of 15 to $25 \%$. The cost of potato seeds reached 40 to $60 \%$ of potato production costs (Gildemacher et al., 2011; Kaur et al., 2015). Therefore, increasing the number and quality of the seed potato, through different agronomic and technique of production, improve the productivity of potato.

According to Ahloowalia (1994), potato mini-tuber production affected by duration of in vitro culture, and explant. Besides these, size of cutting (whole plantlets vs. nodal cuttings) and nodal position (Ali et al., 1995) are among the factors affecting mini-tuber produced. Furthermore, various physiological and agronomic factors such as, age and pre-treatment of plantlets at planting, conditions and period of hardening, time of planting/season, the composition of soil media, fertilizer doses, type of structure under which grown, lights, method of planting, plantlet density, use of plantlets as full or after cutting, irrigation, inter-culture, and crop duration, etc. may affect the mini-tuber production potential of plantlets (Sharma and Pandey, 2013).

Mini-tuber production is affected by genotype (Powell et al., 1989). Cultivars differ widely in their capacity to produce mini-tubers, some being much more productive than others (Venkatasalam et al., 2011; Sharma et al., 2013). A tenfold difference in the yield of mini-tubers between the highest and lowest yielding varieties has been reported by Ahloowalia (1994). Significant differences among the potato cultivars used to establish plantlets in the green houses, canopy cover, number, and yield of mini-tubers have been reported to occur (Kumar et al., $2007 ; 2011)$. Therefore, selecting variety that produces the largest amounts of mini-tubers with appropriate sizes need to be identified and produced for time, economy, and energy efficiency.

The screen house mini-tuber production is aimed to get a large number of diseases free mini- tubers in the short time and low cost of production to restore the farmer who used his/her own rotated seed potatoes for extended years in open field with stored pathogens that resulted in high yield and quality losses (Gildemacher et al., 2009). Even with these significant advancements, the good quality seed remains a constraint of potato productions (Aheisibwe et al., 2015). Therefore, increasing the number and quality of mini-tubers produced in screen house is a substitute less strategies using agronomic and other techniques of production system. This review is aimed to be conducted to assess the information available about different screen house growing media used worldwide and conceptualize for future utilization.

\section{CLEAN POTATO SEEDS}

\section{Importance of clean potato seeds}

The disease-free potato seed play a great role in increasing productivity of potato and improve the livelihood of producers (Hirpa et al. 2010; Otazu 2010; Limenih and Tefera, 2014; Abebe et al., 2014). According to Tessema and Dagne (2018), the yield losses due to the use of poor quality potato seed reach 30 to $50 \%$. The presence of a huge yield difference between good and the poor quality seed was mentioned in Endale et al. (2008). According to Zimba et al. (2014), farmers' who use infected seed tuber revolved for many years without selection led to low productivity of the crop.

\section{Sources of the potato clean seeds}

The sources of the potato clean seed must be an organization or private seed producers that employ tissue culture plantlet development, multiplication followed by micro and/or mini-tuber production under controlled environments. According to the Ethiopian situation, government research centers, especially Holleta Research Center found in Oromia region $37 \mathrm{~km}$ west of Addis Ababa and Adet Research Center found in Amhara region are formal functioning according to the science of diseases free potato mini-tuber production needs in addition to one research institute and other two NGOS. According to Harahagazwe et al. (2018), there are four potato seed producers such as; Adet Agricultural Research Center, Amhara Agricultural Research Institute Laboratory, Organization for Rehabilitation and Development of Amhara and Holetta Agricultural Research Center. This source also indicated solagro plc was also involved in potato seed production and disseminations. Solagro is a licensed company that produces formal potato seeds and sells to the producers (Hirpa et al., 2019). It has its own plant and molecular laboratory (ELISA and qPCR) which is important to certify the phytosanitary quality of seed potatoes (Solagrow PLC, 2011). Due to the less capacity of these mini-tubers producing organization, diseases-free mini-tuber unavailability prevalent and dominant. It requires other strong private sectors that conduct tissue culture and produce mini-tuber under a controlled environment to solve the problem of shortage of diseasesfree seed potatoes to boost the productivity of the crop and improve the producers of potatoes life. According to 
Brasesco et al. (2019), the countrywide production of certified potato seeds covers only 0.2 percent of demand which are 800 tons per year, while the total annual demand for potato seed accounts for approximately 330,000 tones in Ethiopia. All the remaining 329,200 tons are supplied from informal seed produces mainly farmer cooperatives and individual farmers. This informal channel dominates the potato seed supply chain and distribute poor quality potato seeds which resulted in low yields and high incidence of diseases (Brasesco et al., 2019).

\section{TYPE OF SOIL MEDIA USED TO PRODUCE POTATO IN A SCREEN HOUSE}

The soil media provide for the crop nutrient, water, aeration, and support. According to Olle et al. (2012), growing media provide aeration and water, allow for maximum root growth, and physically support the plant. Growing media should have appropriate soil particles sizes distribution which forms an appropriate soil structure with adequate pore spaces (Bilderback et al., 2005). Proper particle size selection or combination is vital for forming light and well-aerated medium that facilitate fast seed germination and emergence, sufficient water holding capacity, strong root growth, and adequate water drainage. Different researches mixed different organic and inorganic media to form good growing media and tested the performance of the media on the basis of the number and weight of tubers the media provided. Obradovic and Sukha (1993) reported a higher yield and number of tubers from vermiculite + sand media as compared to peat moss + sand media combine in the ratio of $4: 1$. Screen house potatoes mini-tuber production uses substrate made of normal soil (e.g., forest soil), sand and peat, or compost at a ratio of 2:1:1 (Parker et al., 2018). In line with these, Harahagazwe et al. (2018), indicated seedbeds in screen houses use a media made of a mixture of soil, sand, and manure in a ratio of 1:1:1 after sterilizing (removing living organisms) by steaming it for approximately 7 to 10 hours. Not only the type of materials mixed but also the ratios of the mixture also have importance on the number and quality of mini-tuber harvested. In research with treatments of perlite, soil, perlite + vermiculite $(1: 1 \mathrm{v} / \mathrm{v})$, perlite + peat moss $(1: 1, \mathrm{v} / \mathrm{v})$, perlite + soil $(1: 1, \mathrm{v} / \mathrm{v})$, perlite + soil + composted cattle manure $(4: 3: 3 \mathrm{v} / \mathrm{v})$, and perlite + soil + vermicompost $(4: 3: 3 \mathrm{v} / \mathrm{v})$, the highest value of particle density and bulk density; and the lowest value of porosity and EC were obtained from the media that contained perlite (Kamrani et al., 2019). The greatest value of leaf chlorophyll index throughout the growing period was observed at perlite + soil + composted cattle manure and perlite + soil + vermicompost. This was likely due to excess availability of $\mathrm{N}$. Substitute media searching for the traditional soilless growing media and chemical fertilizing is also a worry of some of the researches especially, due to expensiveness and less availability of the media as well as the outcome they provide (Douglas, 2020; Zimba et al., 2018). These soilless media mixtures are inorganic substrates added to growing media for physical and chemical property adjustment of the soil for the need of aeration, water holding capacity, and proper drainages. The combination of organic and inorganic substrates promotes nutrient uptake, forms suitable growth and development conditions holding media with optimum water and oxygen holding capacity (Verdonck et al., 1982). Different substrates have several materials that could have direct and/or indirect effects on plant growth and development (Ghehsareh and Kalbasi, 2012). Vermicompost mixed growing media provided increased leaf area, the number of suckers and flowers shoot weight and marketable yield over inorganic fertilizer only (Arancon et al., 2003). Significant increment in yield and yield component due to added vermin-composts on growing media was reported in tomato crop (Gupta et al., 2014; Haghighi et al., 2016). On the other hand, vermiculite had got more importance than other media in providing maximum tuber yield in the green house (Hassanpanah and Khodadadi, 2009). According to Badoni and Chauhan (2010), vermiculite has ability to supply potassium, calcium and magnesium as well as excellent exchange and buffering capacities.

\section{Organic growing media}

Organic components decompose during crop production and change both the physical and chemical properties of the medium (Bilderback et al., 2005) that have a significant effect on the growth, development, and yield of the growing crops. Organic materials include substrates like compost, manure, vermicompost, coffee husk, sawdust, bark, wood chips, peat, fleece, marc, coco soil, and different fruit as well as vegetable factory wastes. These materials are cheap, easily available, and may have a negative impact on the environment (pollution of the environment) when not utilized especially, wastes of factories. While all organic substrates can decompose over time, the rate of decomposition and the physical conditions of the medium vary with the parent material that in turn may affect crop growth and development. For cucumber seedling production, sawdust was proposed as a substitute for high concentrations of peat moss media (Sawan et al., 1999). No significant difference was observed for the growth of tomato transplants cultivated in wood fiber substrates or white peat (Gruda and Schnitzler, 2004). Also, vermicompost could be a substitute for peat in potting media with similar or beneficial effects on seedling performance (emergence and elongation). Most studies have reported beneficial effects of vermicompost on germination, plant growth, and yield with substitutions of 20 to $40 \%$ of vermicompost into a commercial growth medium. These findings indicate that vermicompost enhances the development of vegetables in an organic 
growing medium. Composts are widely used and contain important amounts of nutrients depending on the source and type of compost. Most composts also provide a "warm" growing medium, which promotes root growth. Quicker root growth may help increase subsequent canopy development and overall crop performance. However, crop-specific responses should be considered when using compost and other organic substrates in vegetable production. In tomatoes, variety-specific responses should be considered when developing recommendations on the optimum proportion of vermicompost amendment to the horticultural potting substrate (Zaller, 2007). Although vermicompost may provide a viable alternative to peatbased growth media, overall, Roberts et al. (2007) found a little added benefit from using vermicompost for tomato.

Organic growing media is made of organic matter or plant parts and animal wastes. It is a natural and indigenous source of sustainable plant nutrients that enrich the soil with appropriate plant growing conditions. It releases both micro and macro nutrients need for plant development. Organic matter also contributes a lot to soil structure improvement. It also has great roles in reclaiming soil acidity. Organic matter improves soil workability and water holding capacity. Especially for potatoes where the edible part is found underground, it encourages forming loose, friable, soil with appropriate porosity which easily allows the growth of tubers to required sizes as the crop maximum potentials vary. Some of the organic media used for potato mini tuber production in screen houses are described below.

\section{Compost}

Compost is one of the growing media additives in greenhouse pot, contains a balanced amount of micro and macronutrients which are readily available to the plants. Compost increases the variety and amount of beneficial living organisms in the soil and suppresses the development of damaging living organisms. According to Parker et al. (2018), screen house potatoes mini-tuber production media was made in ratio of 2:1:1 from normal soil (e.g., forest soil), sand and peat/compost. Compost is reported as media used for growing plantlets in screen house (Balali et al., 2008). Materials required and the steps of composting are stated as follows:

1. Collect raw materials for compost (plant material and/or animal feces). Compost made from a combination of greenery and dung has a better composition than compost made from only one of the two. All greenery, including weeds, can be used as raw material for compost.

2. Sort the raw materials. This stage is done to remove pollutants such as plastic, tin cans etc. that will not decompose, and plants infected with diseases (rotten potato, diseased potato plants, etc.) of 1 to 2 meters.
3. To allow air to flow through the compost, stick a piece of bamboo with holes bored in its sides into the middle of the pile.

4. To accelerate composting, starters can be added such as animal internal organs, plant remnant composting bacteria, and/or commercially-available starters.

5. The compost should be turned and observed at least once a month.

6. The composting process occurs when the temperature of the pile increases (up to $60^{\circ} \mathrm{C}$ ).

7. The pile should be watered if it is rather dry and covered when it rains.

8. Take the finished compost. Not all the raw materials in the compost will be decomposed, particularly plant stems, branches, etc. Therefore, the selection of unfinished materials is necessary before the application of compost to the field as well composted is better to be applied than not fully composted ones.

\section{Manure}

Another organic fertilizer used in screen house was manure. Manure is made from animal wastes which function as other organic fertilizers with more nitrogen than compost due to the presence of urine. It can be applied before or after decompositions and the compositions vary with the type of animal. Manure is required in equal ratio with soil and sand for making screen houses seedbed (Harahagazwe et al. (2018). It was also used in combination with perlite and soil in ratio of three manure to four perlite and three soils and resulted in the highest value of bulk density, the lowest value of porosity and EC (exchangeable caution) and the greatest value of leaf chlorophyll index throughout the growing period (Kamrani et al., 2019).

\section{Vermicompost}

The vermicompost can also be used in screen house growth media forming. Vermicompost is the product of composted remains of vegetables, food wastes, sugarcane trash, press mud, sugar factory effluent, broiler ash, spent wash, fruit and vegetable industry wastes using various worms, usually red wigglers, white worms, and other earthworms. It is the end-product of the breakdown of organic matter by an earthworm. These castings have been shown to contain reduced levels of contaminants and a higher saturation of nutrients than organic materials before vermin composting. Vermi compost produced by the activity of earthworms is rich in macro and micronutrients, vitamins, growth hormones, enzymes such as proteases, amylases, lipase, cellulose, and chitinase as well as immobilized microflora (Olle, 2019). The enzymes continue to disintegrate organic matter even after they have been ejected from the worms (Barik et al., 2011). 
Vermicompost usage has multipurpose in one hand environmental pollution controlling, on the other hand decreasing the costs of inorganic fertilizer and supplying the soil with appropriate amendments that do not have long time negative effect on soil like soil acidity.

Vermicompost is an excellent, nutrient-rich organic fertilizer and soil conditioner. According to Olle (2019), vermicompost contains plant nutrients including $\mathrm{N}, \mathrm{P}, \mathrm{K}$, $\mathrm{Ca}, \mathrm{Mg}, \mathrm{S}, \mathrm{Fe}, \mathrm{Mn}, \mathrm{Zn}, \mathrm{Cu}$, and B. Vermicompost and its body liquid (vermiwash) are confirmed as both growth promoters and protectors for crop plants (Adhikary, 2012). The high percentage of humic acids in vermicompost encourages plant health, as it promotes the synthesis of phenolic compounds such as anthocyanins and flavonoids which encourage the plant quality and act as a restraint to pests and diseases (Theunissen et al., 2010). Though it has many advantages for plant, soil, and humankind, it is less utilized in the production system. In my opinion, the use of organic matter for soil amendment has the greatest importance for sustainable agriculture, highly minimizes the soil acidity and shortage of nutrients; creates a safe environment with balanced ecology and good health for human beings.

\section{Inorganic materials used in screenhouse}

\section{Perlite}

In horticulture, perlite can be used as a soil amendment or alone medium for hydroponics or starting cuttings as rooting media and mini-tuber productions. The need for additive is for its good property as it has high permeability and low water retention and prevents soil compaction (ISUENR, 2004) that lacks most in normal soils. In other words, perlite is used in soil mixes (including soilless media) to improve aeration and modify the soil substructure, keeping it loose, well-draining, and defying compaction. An optimum mix ratio of 1:1:1 loam, peat moss, and perlite is used for container growing, enabling the pot to hold just enough water and oxygen (Grant (n.d)). Perlite is a volcanic rock that is crushed and heated rapidly to a high temperature $(1,800 \mathrm{~F})$. It is white colored, lightweight aggregate with high pore space with low waterholding capacity, with almost no CEC or nutrients, and a neutral $\mathrm{pH}$. It does not exist in Ethiopia regardless of its advantages for media additives. There is also surplus raw material for the formation of this important media preparation in the country. Perlite was used alone and with combination of others as treatments for potato pot experiment in different ratios and provided the highest value of particle density and bulk density; as well as the lowest value of porosity and EC from treatments holding perlite (caution exchange capacity) (Kamrani et al., 2019). The greatest value of leaf chlorophyll index throughout the growing period was observed at perlite + soil + composted cattle manure and perlite + soil + vermicompost, likely due to excess availability of $\mathrm{N}$. Other media like sawdust, vermiculit, perlite, sphagnum, peat, pumice, styroform, compost, and sand are used for growing plantlets in screen house (Balali et al., 2008).

\section{Vermiculite}

According to Zimba et al. (2012) and Hassanpanah and Khodadadi (2009) the vermiculite found to have better advantages over other media in that it favors potato growth and improve yield over the other media due to its ability to supply calcium, potassium, and magnesium as well as excellent buffering and exchange capacity (Badoni and Chauhan, 2010). In line with this, a higher yield and number of tubers from vermiculite + sand media was reported by Obradovic and Sukha (1993) as compared to peat moss + sand media combined in the ratio of 4:1. Vermiculite is a silicate material that is heated and expanded into a highly porous lattice structure with better water-retention properties. Vermiculite has several grades from fine, for seed germination, to coarser grades for use as media mixtures. It is sensitive to compaction and contains high CEC (2 - $2.5 \mathrm{meq} / 100 \mathrm{cc})$ and $\mathrm{pH}$ from slightly to very alkaline, based on the sources from which it was made. Vermiculite is also not present in Ethiopia but there is high raw material to process the formation of this media additives.

Moreover, vermiculite had got more importance than other media in providing maximum tuber yield in the green house (Hassanpanah and Khodadadi, 2009). It is used together with other media like sawdust, perlite, sphagnum, peat, pumice, styroform, compost, and sand that are used for growing plantlets in screen house (Balali et al., 2008). According to Zimba et al., (2014), vermiculite very expensive media.

\section{Rock wool}

Rock wool is made from basalt rock and steel mill or other minerals that are liquefied at high temperatures and spun into fibers. The fibers are formed into blocks, or granulated for use as a component of horticultural media. The blocks have high porosity, air space, water-holding capacity, and available water. Rock wool is slightly alkaline and has almost no cation exchange capacity or nutrients. Rock wool is not available and not used in Ethiopia though it is expensive media additives with good quality of potato minituber screen house media productions. Rock wool is used as the best but expensive media in Northen Europe (Zimba et al., 2014).

\section{Polystyrene foam}

Flakes or beads of expanded polystyrene foam are added to media to improve aerations, drainage, and reduce cost. 
They supply no nutrients, CEC, or water-holding capacity and the $\mathrm{pH}$ is neutral.

\section{CONCLUSION}

There are many materials used for screen houses potato mini-tuber production media. Some are expensive and factory processed ones while others are natural. Most reviewed materials used in combination with other materials for the suitability of the crop gown on it as it has to provide sufficient nutrients, aeration, support, and water. Developed countries use expensive media made by factories while the underdeveloped use cheap materials that are easily available in their countries. There is also limited research concerning these materials in developing countries about the ratio of mixing and types to be mixed. The expensive materials used for pot media not found in Ethiopia though there are surplus raw materials for their production. It can be concluded that researchers should work on the availability of healthy and quality tuber seed by increasing the numbers produced in screen house through agronomic and other techniques of production to solving the problems related to potting media.

\section{CONFLICT OF INTEREST}

The author declares no conflict of interest.

\section{REFERENCES}

Abebe, C., Gebremedhin, W. G., Atsede, S., Lemma, T., \& Kassaye, N. (2014). Rapid multiplication techniques (RMTs): A tool for the production of quality seed potato (Solanum tuberosum L.) in Ethiopia. Assian Journal of Crop Science, 6(3), 176-185.

Adhikary, S. (2012). Vermicompost, the story of organic gold: A review. Agricultural Sciences, 3(7), 905-917.

Aheisibwe, A. R., Barekye, A, Namugga, P., \& Byarugaba, A. A. (2015). Challenges and opportunities for quality seed potato availability and production in Uganda. Uganda Journal of Agricultural Science, 16(2), 149-159.

Ahloowalia, B. S. (1994). Production and performance of potato mini-tubers. Euphytica, 75(3), 163-172.

Albajes, R., Gullino, L. M., Van Lantern, J. C., \& Elad, Y. (2002). Integrated pests and diseases management in greenhouse crops. Kluwer Academic Publisher New York. Pp.1-40.

Ali, A., Alam, S. M. M., \& Machado, V. S. (1995). Potato minituber production from nodal cuttings compared to whole in vitro plantlets using low volume media in a greenhouse. Potato Research, 38(1), 69-76.

Arancon, N. Q., Edwards, C. A., Bierman, P., Metzger, J. D., Lee, S., \& Welch, C. (2003). Effects of vermicomposts on growth and marketable fruits of field-grown tomatoes, peppers and strawberries: the 7th international symposium on earthworm ecology. Cardiff. Wales. 2002. Pedobiologia, 47(5-6), 731735.

Badoni, A., \& Chauhan, J. S. (2010). Importance of potato micro tuber seed material for farmers of Uttarakhand Hills. International Journal of Sustainable Agriculture, 2(1), 01-09.

Balali, G. R., Hadi, M. R., Yavari, P., Bidram, H., Naderi, A. G., \& Eslami, A. (2008). Effect of pot size, planting date and genotype on minituber production of Marfona potato cultivar. African Journal of Biotechnology, 7(9), 1265-1270.

Barik, T., Gulati, J. M. L., Garnayak, L. M., \& Bastia, D. K. (2010). Production of vermicompost from agricultural wastes- A review. Agricultural Reviews, 31(3), 172-183.

Bilderback, T. E., Warren, S. L., Owen, J. S., \& Albano, J. P. (2005). Healthy substrates need physicals too!. HortTechnology, 15(4), 747-751.

Brasesco, F., Asgedom, D., \& Casari, G (2019). Strategic analysis and intervention plan for potatoes and potato products in the Agro-Commodities Procurement Zone of the pilot Integrated Agro-Industrial Park in Central Eastern Oromia, Ethiopia. Addis Ababa, FAO. 80 pp. Licence: CC BY-NC-SA 3.0 IGO.

Douglas, C. (2020). Agriculture, Food, and Environment. Greenhouse Crop and Floriculture program. Organic Growing Media and Fertilizers for Greenhouses. Plant, Soil and Insect Sciences, University of Massachusetts, Amherst 08.

Endale, G., Gebremedhin, W., \& Berga, L. (2008). Potato seed management. In: Gebremedhin, W., Endale, G., \& Berga, L. (eds.), Root and tuber crops: The untapped resources. Ethiopian Institute of Agricultural Research (EIAR). Pp. 54-66.

Ghehsareh, A. M., \& Kalbasi, M. (2012). Effect of addition of organic and inorganic combinations to soil on growing property of greenhouse cucumber. African Journal of Biotechnology, 11(37), 9102-9107.

Gildemacher, P. R., Demo, P., Barker, I., Kaguongo, W., Woldegiorgis, G., Wagoire, W. W., Wakahiu, M., Leeuwis, C., \& Struik, P. C. (2009). A description of seed potato systems in Kenya, Uganda and Ethiopia. American Journal of Potato Research, 86(5), 373-382.

Gildemacher, P. R., Schulte-Geldermann, E., Borus, D., Demo, P., Kinyae, P., Mundia, P., \& Struik, P. C. (2011). Seed potato quality improvement through positive selection by smallholder farmers in Kenya. Potato Research, 54(3), 253-266.

Grant, A. (n.d). What is perlite: Learn about perlite potting soil. Retrieved from https://www.gardeningknowhow.com/gardenhow-to/soil-fertilizers/perlite-potting-soil.htm.

Gruda, N., \& Schnitzler, W. H. (2004). Suitability of wood fiber substrates for production of vegetable transplants II.: The effect of wood fiber substrates and their volume weights on the growth of tomato transplants. Scientia Horticulturae, 100(1-4), 333-340.

Gupta, R., Yadav, A., \& Garg, V. K. (2014). Influence of vermicompost application in potting media on growth and flowering of marigold crop. International Journal of Recycling of Organic Waste in Agriculture, 3, 47.

Haghighi, M., Barzegar, M. R., \& da Silva, J. A. T. (2016). The effect of municipal solid waste compost, peat, perlite and vermicompost on tomato (Lycopersicum esculentum L.) growth and yield in a hydroponic system. International Journal of Recycling of Organic Waste in Agriculture, 5(3), 231-242.

Harahagazwe, D., Andrade-Piedra, J. L., Parker, M., \& SchulteGeldermann, E. (2018). Current situation of rapid multiplication techniques for early generation seed potato production in SubSaharan Africa. Lima (Peru). 46 p. RTB Working Paper. ISSN 2309-6586. no.2018-1.

Harahagazwe, D., Andrade-Piedra, J. L., Parker, M., \& SchulteGeldermann, E. (2018). RTB working paper. Current situation 
of rapid multiplication techniques for early generation seed potato production in sub-saharan Africa. RTB Program Management Unit, International Potato Center (CIP) Apartado 1558, Lima 12, Peru.

Hassanpanah, D., \& Khodadadi, M. (2009). Study the plantlet age effect and planting beds on Agria potato mini-tuber production under in vivo condition. Journal of Biological Sciences, 9(3), 243-248.

Hirpa, A., Meuwissen, M. P. M., Lommen, W. J. M., Oude Lansink, A. G. J. M., Tsegaye, A., \& Struik, P. C. (2019). Improving seed potato quality in Ethiopia: A value chain perspective (Chapter 5). In: Bijman, J., \& Bitzer, V. (eds.). Quality and innovation in food chains: Lessons and insights from Africa. Wageningen Academic Publishers. Pp. 101-118.

Hirpa, A., Meuwissen, M. P., Tesfaye, A., Lommen, W. J., Lansink, A. O., Tsegaye, A., \& Struik, P. C. (2010). Analysis of seed potato systems in Ethiopia. American Journal of Potato Research, 87(6), 537-552.

ISUENR (lowa State University Extension News Release) (2004). Archived from the original on 2004-03-23.

Kamrani, H., \& Chegeni, R. (2019). Effects of Different Growing Media on Yield and Growth Parameters of Potato Minitubers (solanum Tuberosum L.). Communications in Soil Science and Plant Analysis, 50(15), 1838-1853.

Kaur, M., Kaur, R., Sharma, C., Kaur, N., \& Kaur, A. (2015). Effect of growth regulators on micropropagation of potato cultivars. African Journal of Crop Science, 3(5), 162-164.

Kumar, D., Singh, V., \& Singh, B. P. (2011). Growth and yield of potato plants developed from in vitro plantlets in net house. Potato Journal, 38(2), 143-48.

Kumar, D., Singh, V., Singh, R. P., Singh, B. P., \& Naik, P. S. (2007). Performance of in vitro plantlets for production of mini tubers in vector free environment. Potato Journal, 34(1-2), 131-32.

Limenih, B., \& Tefera, T. (2014). Knowledge gaps in potato technology adoption: The case of central highlands of Ethiopia. Journal of Agricultural Extension and Rural Development, 6(8), 259-266.

Mobini, S. H., Ismail, M. R., \& Arouiee, H. (2009). Influence of ventilation and media on potato (Solanum tuberosum L.) tuberization and its growth characteristics. African Journal of Biotechnology, 8(10), 2232-2241.

Obradovic, A., \& Sukha, C. (1993). Effect of different potting mixes on potato mini tuber production. Journal of Scientific Agricultural Research (Yugoslavia), 53(193-196), 39-45.

Olle, M. (2019). vermicompost, its importance and benefit in agriculture. Journal of Agricultural Science, 30(2), 93-98.

Otazu V. (2010). Manual on quality seed potato production using aeroponics. Lima (Peru) International Potato Center (CIP), p. 42.

Harahagazwe, D., Andrade-Piedra, J. L., Parker, M., \& SchulteGeldermann, E. (2018). Current situation of rapid multiplication techniques for early generation seed potato production in SubSaharan Africa. RTB Working Paper, RTB Program Management Unit International Potato Center (CIP) Apartado 1558, Lima 12, Peru. Retrieved from https://cgspace.cgiar.org/handle/10568/96609.
Powell, W., Brown, J., \& Caligari, P. D. S. (1989) Variability in the response of potato cultivars to micro-propagation II. Subsequent field performance. Annal of Applied Biology, 115(1), 123-128.

Roberts, P., Jones, D. L., \& Edwards-Jones, G. (2007). Yield and vitamin $C$ content of tomatoes grown in vermicomposted wastes. Journal of the Science of Food and Agriculture, 87(10), 1957-1963.

Roy, B. (2014). Farmers' participatory quality seed production of field crops-A case study. Journal of Crop and Weed, 10(2), 8993.

Sawan, O. M., Eissa, A. M., \& Abou-Hadid, A. F. (1999). The effect of different growing media on cucumber seedling production, fruit yield and quality under greenhouse conditions. Acta Horticulturae. 491, 369-376.

Sharma, A. K., \& Pandey, K. K. (2013). Potato mini-tuber production through direct transplanting of in vitro plantlets in green or screen houses-a review. Potato Journal, 40(2), 95103.

Sharma, K. A., Venkatasalam, E. P., \& Kumar, V. (2013). Potato mini-tuber production during main and off crop seasons in high hills of north-western Himalaya. Potato Journal, 40(1), 29-37.

Solagrow PLC (2011). About solagrow. Retrieved from http://www.solagrowplc.com/about-solagrow.

Tessema, L., \& Dagne, Z. (2018). Aeroponics and Sand Hydroponics: Alternative technologies for pre-basic seed potato production in Ethiopia. Open Agriculture, 3(1), 444-450.

Theunissen, J., Ndakidemi, P. A., \& Laubscher, C. P. (2010). Potential of vermicompost produced from plant waste on the growth and nutrient status in vegetable production. International Journal of the Physical Sciences, 5(13), 19641973.

Venkatasalam, E. P., Jyoti, L., Shilpa, S., Sumita, S., Sharma, A. K., Sneh, S., Rishu, P., \& Sarjeet, S. (2011). In vitro and in vivo performance of potato cultivars for different seed production systems. Potato Journal, 38(2), 149-154.

Verdonck, O. D., De Vleeschauwer, D., \& De Boodt, M. (1981, August). The influence of the substrate to plant growth. In Symposium on Substrates in Horticulture other than Soils In Situ 126 (pp. 251-258).

Zaller, J. G. (2007). Vermicompost as a substitute for peat in potting media: Effects on germination, biomass allocation, yields and fruit quality of three tomato varieties. Scientia Horticulturae, 112(2), 191-199.

Zimba, S. C., Njoloma, J. P., Nyaika, J. A., Mwase, W. F., Maliro, M. F., Bokosi, J. M., \& Kwapata, M. B. (2014). Minituber production potential of selected Potato (Solanum tuberosum L.) genotypes in different propagation media. African Journal of Biotechnology, 13(48), 4430-4437. 